\title{
Determination of Trace Elements in Aerosols at a Rural Mountainous Area and a Local City of Eastern Shikoku Region, Japan
}

\author{
Yuhei Yamamoto, ${ }^{* \dagger}$ Yosuke Sanagawa,** and Shoji ImaI* \\ *Division of Chemistry, Institute of Natural Science, Graduate School of Technology, Industrial and Social \\ Sciences, Tokushima University, 2-1 Minamijosanjima, Tokushima 770-8506, Japan \\ **Department of Chemistry, Graduate School of Integrated Arts and Sciences, The University of Tokushima, \\ 1-1 Minamijosanjima, Tokushima 770-8502, Japan
}

\begin{abstract}
A simple digestion method for a mixed cellulose membrane filter in order to analyze trace elements in aerosols was examined. The determination of $\mathrm{Cu}, \mathrm{Fe}$ and $\mathrm{Ni}$ in the certified reference materials of China loess (CJ-1) could be conducted using the digestion method. Trace elements in aerosols smaller than $10 \mu \mathrm{m}$ size collected at Tokushima City and near mountain areas for each season were determined as a water-soluble fraction and all components by the digestion method. Back trajectory analysis implied that the contribution from the Asian continent was larger in the winter and spring than the summer. Systematic changes in the trace element compositions for each season were not observed, except for Fe, Th and U. Water-soluble components in aerosols at Tokushima City showed higher concentrations of all trace elements than those of the mountain areas. For aerosols in Tokushima City and near to the mountain areas, $\mathrm{As}, \mathrm{Bi}, \mathrm{Cd}$, $\mathrm{Cu}$ and $\mathrm{Pb}$ were mainly derived from anthropogenic sources, whereas $\mathrm{Ba}, \mathrm{Co}, \mathrm{Cs}, \mathrm{Ga}, \mathrm{Mn}, \mathrm{Rb}, \mathrm{Sr}, \mathrm{Th}, \mathrm{U}$ and $\mathrm{V}$ were derived from natural crustal sources. The origin of $\mathrm{Pb}$ and $\mathrm{Cd}$ was considered based on the $\mathrm{Pb} / \mathrm{Cd}$ ratio.
\end{abstract}

Keywords Aerosols, filter digestion, trace elements, water-soluble

(Received January 13, 2020; Accepted March 30, 2020; Advance Publication Released Online by J-STAGE April 3, 2020)

\section{Introduction}

Trace elements in atmospheric aerosols play an important role on concerning to transport of biogeochemical micronutrients for marine ecosystems, such as $\mathrm{Fe},{ }^{1,2} \mathrm{Co},{ }^{3,4} \mathrm{Mn},{ }^{5} \mathrm{Ni},{ }^{6,7}$ and $\mathrm{Cu}^{8}$ In the ocean, the distribution and behavior of these micronutrients have been investigated for such trace elements. ${ }^{8,9}$ On the other hand, the distribution of $\mathrm{Pb}$ as a toxic element was also investigated for surface water in the open ocean. ${ }^{10}$ It is well known that these trace elements are included not only in crustal aerosols, but also in anthropogenic aerosols, mainly derived from coal, petroleum, and domestic waste combustion and industrial activities. ${ }^{11,12}$ The long-range transport of aerosols is important as a transport process of trace elements from the Asian continent, where the dominant emission source of crustal and anthropogenic aerosols exist, to the ocean. ${ }^{11-15}$

Because the solubility of the trace elements in the ocean, which depends on the chemical state, affects to the bioavailability for marine microbe, the solubility of trace elements in aerosols is important. ${ }^{16,17}$ Evaluating the solubility of trace elements was conducted by determining the chemical state of trace elements using XAFS. ${ }^{17-21}$ Extraction experiments of trace elements were also used to evaluate the solubility. ${ }^{11,22}$ In the latter case, the decomposition of aerosols on the sampling filter is required in order to determine the fraction of the water-soluble contents to the whole content. The Ministry of the Environment and the

† To whom correspondence should be addressed.

E-mail: yamamoto.yuhei@tokushima-u.ac.jp
National Institute for Environmental Studies proposed a sampling method using a PTFE filter for inorganic components due to a low abundance of impurities. ${ }^{23}$ However, the decomposition of a PTFE filter requires hydrofluoric acid and pressure vessel for microwave assisted decomposition instrument. Therefore, procedure of the pretreatment for PTFE filter is complicated. The aim of this study is to simplify the pretreatment method for the analysis of inorganic component in aerosols. We conducted sampling using a mixed cellulose ester (MCE) membrane filter, because a MCE filter can be decomposed without hydrofluoric acid, pressure vessel and microwave digestion. To evaluate the new method, trace elements were determined for certified reference materials of China loess (CJ-1), which is the origin of Kosa, and environmental aerosol samples collected from Tokushima City and a neighboring rural mountain, which are located in a channel from Kansai Area to the Kuroshio Current in the Northwestern Pacific Ocean. To discuss the solubility of trace elements, both the acid-soluble and water-soluble fractions were measured. Environmental aerosol samples were collected from a local city at a low altitude $(15 \mathrm{~m})$ and a rural mountain area at a high altitude $(700$ and $850 \mathrm{~m})$ to understand the distribution of each trace element. At a lower altitude point, aerosol samples were collected every month to understand the seasonal variation.

\section{Experimental}

Location and sampling

Figure 1 shows the sampling sites. St. 1 is located at the top 
of a building of Tokushima University in Tokushima City, Tokushima Prefecture $\left(34^{\circ} 4^{\prime} 39^{\prime \prime} \mathrm{N}, 134^{\circ} 33^{\prime} 38^{\prime \prime}\right.$ E; altitude, $15 \mathrm{~m})$ as a local city area, where some anthropogenic emission sources exist. St. 2 and St. 3 were Ogawara Kohgen ( $33^{\circ} 57^{\prime} 32^{\prime \prime}$ $\left.\mathrm{N}, 134^{\circ} 25^{\prime} 18^{\prime \prime} \mathrm{E}, 700 \mathrm{~m}\right)$ and Gakujin no Mori $\left(33^{\circ} 55^{\prime} 32^{\prime \prime} \mathrm{N}\right.$, $134^{\circ} 16^{\prime} 16^{\prime \prime} \mathrm{E}, 850 \mathrm{~m}$ ) in the eastern part of Shikoku Island, Japan, where no anthropogenic emission source exists nearby. St. 2 and St. 3 were selected as high-altitude rural sites in the atmospheric boundary layer, which were 17 and $35 \mathrm{~km}$ distance from St. 1, respectively. Tokushima City is about $100 \mathrm{~km}$ distance from Osaka, where many anthropogenic emission sources exist, and about $100 \mathrm{~km}$ distance from Tokushima City to the north end of Kuroshio Current through Kii Channel. Only aerosols smaller than $10 \mu \mathrm{m}$, such as $\mathrm{PM}_{10}$ and $\mathrm{PM}_{2.5}$, could be transported over $30 \mathrm{~km}$ during convectional air

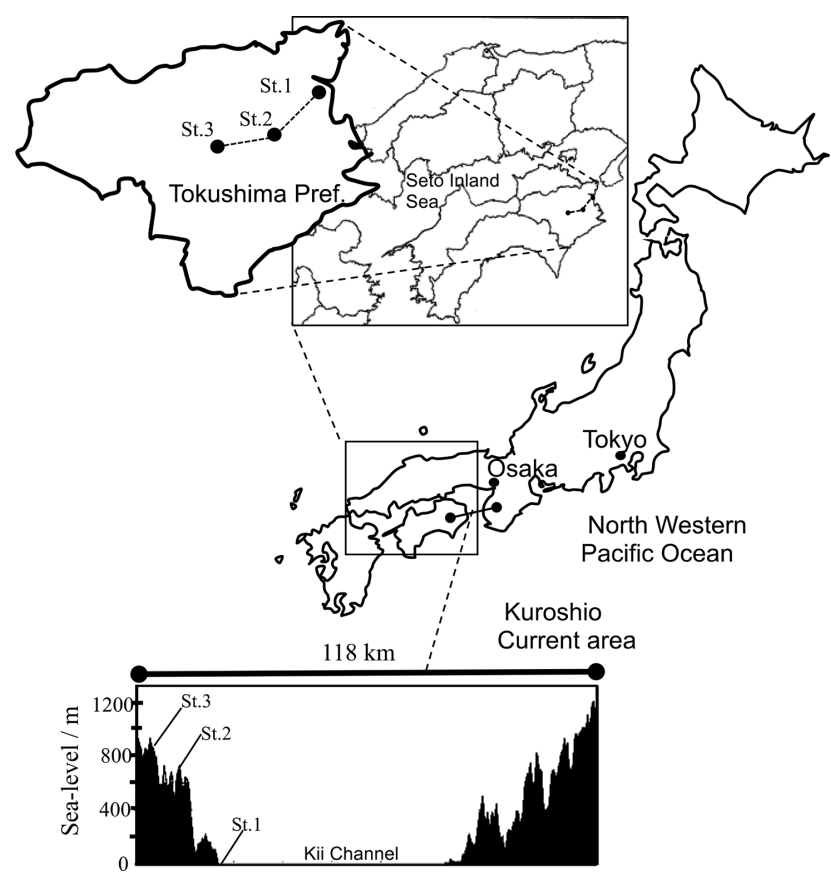

Fig. 1 Locations of sampling sites. St. 1, Tokushima City; St. 2, Oogawara Kogen; St. 3, Gakujin no Mori. circulation in the boundary layer. An aerosol sample was collected by a low-volume air sampler (SHIBATA C30) with a $0.45-\mu \mathrm{m}$ MCE membrane filter (ADVANTEC, diameter $47 \mathrm{~mm}$ ), placed at a height of $1 \mathrm{~m}$ above the ground level. This sampler has an availability of $100 \%$ cut-off above 10 and $7.07 \mu \mathrm{m}$ particles at 30 and $9.6 \mathrm{~L} \mathrm{~min}^{-1}$, respectively. In this study, air flow of $20 \mathrm{~L} \mathrm{~min}^{-1}$ was used, corresponding to $8.24 \mu \mathrm{m}$ of the cut-off diameter. Aerosol samples were collected from Jul. 2012 to Dec. 2013. The sampling period, air volume and average wind speed are given in Table 1. Here, the periods of Nov. - Feb., Mar. - May and Jun-Oct. were defined as the winter, spring and summer seasons, respectively. The concentration of $\mathrm{PM}_{2.5}$ in China was maximum during the sampling period ${ }^{24}$ due to the largest amount of coal consumption in the past. It is likely that large amounts of anthropogenic aerosols from the Asian continent were found in our samples.

\section{$\mathrm{HNO}_{3}-\mathrm{H}_{2} \mathrm{O}_{2}$ digestion}

An acid-soluble fraction in an aerosol sample was digested by a $\mathrm{HNO}_{3}-\mathrm{H}_{2} \mathrm{O}_{2}$ solution without $\mathrm{HF}$, where a reagent grade of those reagents were used. A $1 / 8$ cut portion of a filter after sample collection was digested in a $20-\mathrm{mL}$ of a PFA vessel (ASONE). An aliquot of the sample was digested using a mixture of comprising $3 \mathrm{~mL}$ of $69 \% \mathrm{HNO}_{3}$ and $3 \mathrm{~mL}$ of $30 \%$ $\mathrm{H}_{2} \mathrm{O}_{2}$ heating up to $160^{\circ} \mathrm{C}$ on a hot plate with a PTFE evaporation chamber (SAN-AI Kagaku A-1) equipped with a clean air pump (SAN-AI Kagaku Clean Air Z) after $10 \mathrm{~h}$ of immersion. No residual particles were observed in the digested solutions. After drying on a hot plate, the dried sample was dissolved in $6 \mathrm{~mL}$ of $2 \% \mathrm{HNO}_{3}$. After this procedure, trace elements were determined by ICP-MS. The filter blanks were obtained according to an identical procedure for a whole filter before use at each sampling period. In order to examine the accuracy, the concentrations of $\mathrm{Al}, \mathrm{Si}$ and $\mathrm{Fe}$ as major components more than $2 \mathrm{wt} . \%$ and those of $\mathrm{Co}$ and $\mathrm{Ni}$ as minor components less than $100 \mathrm{mg} \mathrm{kg}^{-1}$ in the certified reference material of China loess (CJ-1) were determined by the GFAAS technique after different procedures of $\mathrm{HNO}_{3}-\mathrm{H}_{2} \mathrm{O}_{2}$ digestion with and without $\mathrm{HF}$. After $\mathrm{HNO}_{3-}$ $\mathrm{H}_{2} \mathrm{O}_{2}$ digestion, coarse alminosilicate particles may exist in the sample solution because CJ-1 contains refractory alminosilicate minerals. These particles could not be detected by ICP-MS due to the sample introduction mechanism. Therefore, the sample solution of CJ-1 was measured by GFAAS.

Table 1 Sampling date, air volume and average wind speed

\begin{tabular}{|c|c|c|c|c|c|}
\hline Site & Season & Start - end (yy.mm.day; h:min) & Time/min & Volume $/ \mathrm{m}^{3}$ & Wind $/ \mathrm{m} \mathrm{s}^{-1}$ \\
\hline \multirow[t]{16}{*}{ St. 1 Tokushima City } & \multirow[t]{5}{*}{ Winter } & 2013.Jan.17; 18:00 - Jan.21; 20:00 & 5880 & 117.6 & 3.8 \\
\hline & & 2013.Jan.22; 18:00 - Jan.25; 18:00 & 4320 & 86.4 & 3.6 \\
\hline & & 2013.Feb.01; 18:00 - Feb.04; 19:30 & 4410 & 88.2 & 3.6 \\
\hline & & 2013.Nov.18; 18:00 - Nov.23; 00:00 & 6120 & 122 & 3.4 \\
\hline & & 2013.Dec.24; 20:30 - Dec.28; 00:10 & 4540 & 90.8 & 3.2 \\
\hline & \multirow[t]{3}{*}{ Spring } & 2013.Mar.26; 18:00 - Mar.30; 18:00 & 5760 & 86.4 & 2.7 \\
\hline & & 2013.Apr.29; 18:00 - May.03; 20:00 & 5780 & 88.8 & 3.1 \\
\hline & & 2013.May.21; 18:00 - May.24; 18:00 & 4320 & 86.4 & 2.4 \\
\hline & \multirow[t]{8}{*}{ Summer } & 2012.Jul.20; 15:00 - Jul.24; 16:00 & 5820 & 116.4 & 3.6 \\
\hline & & 2012.Aug.10; 15:00 - Aug.17; 18:00 & 10260 & 199.2 & 2.9 \\
\hline & & 2012.Sep.21; 14:00 - Sep.25; 23:00 & 6300 & 126.0 & 3.8 \\
\hline & & 2013.Jun.18; 20:30 - Jun.21; 18:30 & 4200 & 84.0 & 2.0 \\
\hline & & 2013.Jul.26; 18:40 - Aug.01; 05:50 & 7870 & 157.4 & 2.0 \\
\hline & & 2013.Aug.23; 18:00 - Aug.28; 13:30 & 6930 & 138.6 & 2.4 \\
\hline & & 2013.Sep.30; 18:00 - Oct.04; 21:00 & 5940 & 118.8 & 3.0 \\
\hline & & 2013.Oct. $22 ; 17: 30$ - Oct.25; 18:00 & 4350 & 87.0 & 4.4 \\
\hline St. 2 Oogawara Kohgen & Winter & 2012.Nov.10; 13:00 - Nov.14; 12:00 & 5700 & 114.0 & 4.1 \\
\hline St. 3 Gakujin no Mori & Winter & 2012.Nov.24; 11:00 - Nov.28; 14:00 & 5940 & 118.8 & 3.6 \\
\hline
\end{tabular}




\section{Water extraction}

A $1 / 8$ cut portion of the filter and the volume of water diluted sample solution in a $50-\mathrm{mL}$ polypropylene centrifuge tube (TPP ${ }^{\circledR}$ ) were calibrated by weight. The water-soluble component was obtained from a supernatant solution after being centrifuged at $1000 \mathrm{rpm}$ for $20 \mathrm{~min}$ of a $15-\mathrm{h}$ extracted sample by $20 \mathrm{~mL}$ of Milli-Q water (Millipore Milli-Q academic). The supernatant solution was prepared to a $2 \% \mathrm{HNO}_{3}$ matrix after removing the filter. After that, trace elements were determined by ICP-MS The filter blanks were obtained according to an identical procedure for a whole filter before use. The concentrations of trace elements in the supernatant solution reached to a constant value independently at times between 6 and $32 \mathrm{~h}$. The waterextraction time of $15 \mathrm{~h}$ was selected. The fraction extracted from aerosol by water was defined as the "water-soluble" fraction $\left([\mathrm{M}]_{\mathrm{ws}}\right)$.

\section{ICP-MS analysis}

The determination of trace elements was subsequently performed using a Thermo Fisher Scientific X-2 series ICP-MS equipped with a $\mathrm{He} / \mathrm{H}_{2}$-collision cell unit, which was placed in the room providing atmosphere cleaned by HEPA filter. Concerning the operating parameters of ICP-MS measurements, an RF power of $1.4 \mathrm{~kW}$, Ar cool gas of $13.0 \mathrm{~L} \mathrm{mim}^{-1}$, auxiliary gas of $0.80 \mathrm{~L} \mathrm{~min}^{-1}$ and nebulizer gas of $0.85 \mathrm{~L} \mathrm{~min}^{-1}$ were employed. The number of repetitions was four. The standard operation mode was employed for ${ }^{137} \mathrm{Ba},{ }^{209} \mathrm{Bi},{ }^{111} \mathrm{Cd},{ }^{59} \mathrm{Co},{ }^{133} \mathrm{Cs}$, ${ }^{65} \mathrm{Cu},{ }^{69} \mathrm{Ga},{ }^{55} \mathrm{Mn},{ }^{208} \mathrm{~Pb},{ }^{85} \mathrm{Rb},{ }^{88} \mathrm{Sr},{ }^{232} \mathrm{Th},{ }^{238} \mathrm{U}$ and ${ }^{51} \mathrm{~V}$. The collision cell mode was employed for ${ }^{75} \mathrm{As}$ and ${ }^{57} \mathrm{Fe}$ in order to reduce the any molecular ion forming interference. The $\mathrm{He} / \mathrm{H}_{2}$ mix gas flow rate was $3.5 \mathrm{~mL} \mathrm{~min}{ }^{-1}$, which gave cerium oxide to cerium ratios $\left({ }^{140} \mathrm{Ce}^{16} \mathrm{O}:{ }^{140} \mathrm{Ce}\right)$ of $<0.1 \%$. A $10 \mu \mathrm{g} \mathrm{L}{ }^{-1}$ of $\mathrm{Ge}$ and $\mathrm{Rh}$ solution was used as the internal standard. Calibration standards were prepared by the serial dilution of a multielemental standard (XSTC-13, SPEX) with 2\% (v/v) $\mathrm{HNO}_{3}$ matrix. Water was prepared by a system of Milli-Q academic after Elix-5 (Millipore). The detection limits were defined as the equivalent concentration of three times the standard deviation on five measurements of a blank solution. Although the detection limits varied from day to day, the concentration of the above elements in most of the digested sample solution surpassed the detection limits of ICP-MS, and could be determined without any further preconcentration. The mean value of the detection limits of the ICP-MS are given in Table 2.

\section{Results and Discussion}

\section{Backwards trajectory analysis}

A backwards trajectory analysis of the air mass was conducted by the NOAA HYSPLIT ${ }^{25}$ (archive trajectories) system for $48 \mathrm{~h}$ of the trajectory run time at every $12 \mathrm{~h}$. The height of the

Table 2 Average values and the standard deviation of limit of detection by blank runs

\begin{tabular}{ccclcc}
\hline & $\begin{array}{c}\text { Solutiona/ } \\
\text { ng dm }^{-3}\end{array}$ & $\begin{array}{c}\text { Atmospheric/ } \\
\mathrm{pg} \mathrm{m}^{-3}\end{array}$ & & $\begin{array}{c}\text { Solution/ } \\
\mathrm{ng} \mathrm{dm}^{-3}\end{array}$ & $\begin{array}{c}\text { Atmospheric/ } \\
\mathrm{pg} \mathrm{m}^{-3}\end{array}$ \\
\hline $\mathrm{As}$ & $63 \pm 39$ & $46 \pm 10$ & $\mathrm{Ga}$ & $1.0 \pm 0.7$ & $0.7 \pm 0.2$ \\
$\mathrm{Ba}$ & $9.1 \pm 8.8$ & $6.6 \pm 1.4$ & $\mathrm{Mn}$ & $4.5 \pm 2.7$ & $3.3 \pm 0.7$ \\
$\mathrm{Bi}$ & $0.77 \pm 0.80$ & $0.6 \pm 0.1$ & $\mathrm{~Pb}$ & $2.5 \pm 2.7$ & $1.8 \pm 0.4$ \\
$\mathrm{Cd}$ & $1.6 \pm 0.9$ & $1.2 \pm 0.2$ & $\mathrm{Rb}$ & $2.2 \pm 1.7$ & $1.6 \pm 0.3$ \\
$\mathrm{Co}$ & $1.0 \pm 0.5$ & $0.7 \pm 0.2$ & $\mathrm{Sr}$ & $2.1 \pm 2.5$ & $1.5 \pm 0.3$ \\
$\mathrm{Cs}$ & $0.34 \pm 0.32$ & $0.2 \pm 0.1$ & $\mathrm{Th}$ & $0.49 \pm 0.41$ & $0.4 \pm 0.1$ \\
$\mathrm{Cu}$ & $13 \pm 12$ & $9.2 \pm 1.9$ & $\mathrm{U}$ & $0.13 \pm 0.1$ & $0.1 \pm 0.0$ \\
$\mathrm{Fe}$ & $110 \pm 30$ & $82 \pm 17$ & $\mathrm{~V}$ & $8.3 \pm 11$ & $6.0 \pm 1.3$ \\
\hline
\end{tabular}

a. Statistic calculation were carried out by using L.O.D. values at every sampling event.

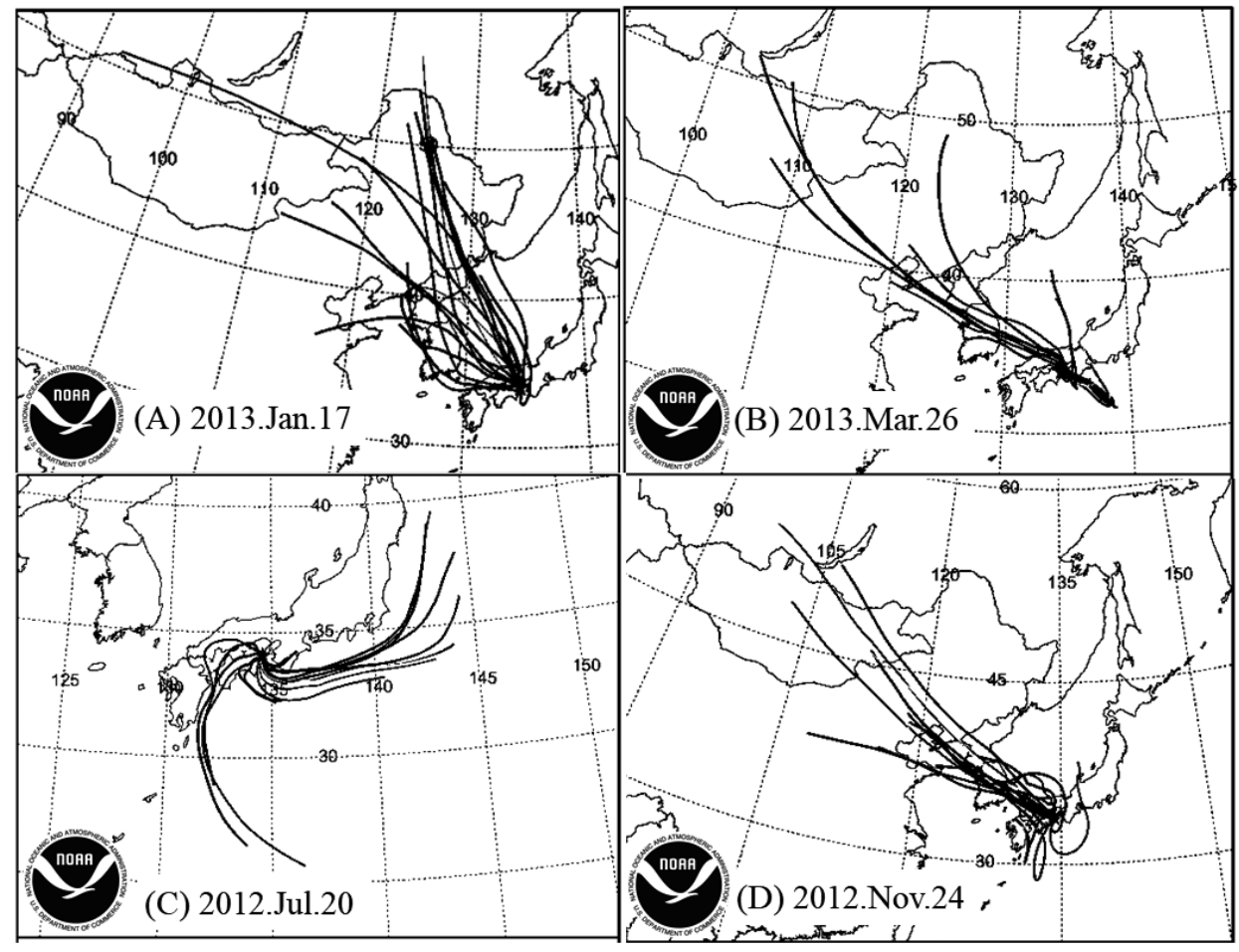

Fig. 2 Typical examples of backward trajectories at $500 \mathrm{~m}$ (A, B, C) and $1000 \mathrm{~m}$ sea level (D) during sampling. A, St. 1 in winter; B, St. 1 in spring; C, St. 1 in summer; D, St. 3 in winter. 
Table 3 Analytical results of certified reference material of China Loess (CJ-1)

\begin{tabular}{|c|c|c|c|c|c|c|}
\hline \multirow{2}{*}{ CJ-1 } & \multicolumn{2}{|c|}{$\mathrm{Cu} / \mu \mathrm{g} \mathrm{g}^{-1}$} & \multicolumn{2}{|c|}{$\mathrm{Ni} / \mu \mathrm{g} \mathrm{g}^{-1}$} & \multicolumn{2}{|c|}{$\mathrm{Fe}, \%$} \\
\hline & Ave. \pm SD & Recovery & Ave. \pm SD & Recovery & Ave. \pm SD & Recovery \\
\hline Certified value & $21 \pm 3$ & 1.00 & $31 \pm 3$ & 1.00 & $2.94 \pm 0.09$ & 1.00 \\
\hline $\mathrm{HNO}_{3}+\mathrm{H}_{2} \mathrm{O}_{2}$ & $19.0 \pm 0.4$ & 0.90 & $34.0 \pm 1.4$ & 1.10 & $2.78 \pm 0.23$ & 1.03 \\
\hline $\mathrm{HNO}_{3}+\mathrm{H}_{2} \mathrm{O}_{2}+\mathrm{HF}$ & $22.4 \pm 0.5$ & 1.07 & $32.5 \pm 1.9$ & 1.05 & $2.91 \pm 0.17$ & 0.98 \\
\hline
\end{tabular}

Table 4 Average concentrations trace elements in acid-soluble and water-solublefractions

\begin{tabular}{|c|c|c|c|c|c|c|c|}
\hline & & \multicolumn{3}{|c|}{ Tokushima City (winter) } & \multicolumn{3}{|c|}{ Tokushima City (spring) } \\
\hline & & {$[\mathrm{M}]_{\text {all }}$} & {$[\mathrm{M}]_{\mathrm{ws}}$} & {$[\mathrm{M}]_{\mathrm{ws}} /[\mathrm{M}]_{\mathrm{all}}$} & {$[\mathrm{M}]_{\text {all }}$} & {$[\mathrm{M}]_{\mathrm{ws}}$} & {$[\mathrm{M}]_{\mathrm{ws}} /[\mathrm{M}]_{\text {all }}$} \\
\hline As & $\mathrm{ng} \mathrm{m}^{-3}$ & $1.67 \pm 0.67$ & $1.30 \pm 0.7$ & 0.78 & $2.53 \pm 0.98$ & $2.46 \pm 1.41$ & 0.97 \\
\hline $\mathrm{Ba}$ & $n g \mathrm{~m}^{-3}$ & $3.62 \pm 0.41$ & $1.20 \pm 1.22$ & 0.33 & $5.96 \pm 2.53$ & $4.12 \pm 1.82$ & 0.69 \\
\hline $\mathrm{Bi}$ & $\mathrm{pg} \mathrm{m}^{-3}$ & $404 \pm 109$ & $86 \pm 55$ & 0.21 & $514 \pm 200$ & $121 \pm 60$ & 0.24 \\
\hline $\mathrm{Cd}$ & $\mathrm{pg} \mathrm{m}^{-3}$ & $431 \pm 152$ & $301 \pm 140$ & 0.70 & $529 \pm 143$ & $477 \pm 220$ & 0.90 \\
\hline Co & $\mathrm{pg} \mathrm{m}^{-3}$ & $59 \pm 24$ & $24 \pm 6$ & 0.41 & $72 \pm 25$ & $47 \pm 21$ & 0.65 \\
\hline $\mathrm{Cs}$ & $\mathrm{pg} \mathrm{\textrm {m } ^ { - 3 }}$ & $124 \pm 42$ & $92 \pm 54$ & 0.74 & $163 \pm 93$ & $123 \pm 68$ & 0.75 \\
\hline $\mathrm{Cu}$ & $\mathrm{ng} \mathrm{m}^{-3}$ & $4.27 \pm 2.86$ & $2.01 \pm 0.53$ & 0.47 & $3.73 \pm 1.77$ & $2.53 \pm 0.71$ & 0.68 \\
\hline $\mathrm{Fe}$ & $\mathrm{ng} \mathrm{m}^{-3}$ & $146 \pm 18.9$ & $8.70 \pm 2.9$ & 0.06 & $336 \pm 188.7$ & $26.0 \pm 13.6$ & 0.08 \\
\hline $\mathrm{Ga}$ & $\mathrm{pg} \mathrm{m}^{-3}$ & $382 \pm 206$ & $255 \pm 110$ & 0.67 & $305 \pm 94$ & $289 \pm 114$ & 0.95 \\
\hline Mn & $n g \mathrm{~m}^{-3}$ & $5.65 \pm 1.37$ & $3.39 \pm 1.03$ & 0.60 & $7.24 \pm 2.43$ & $7.68 \pm 4.36$ & 1.0 \\
\hline $\mathrm{Pb}$ & $\mathrm{ng} \mathrm{m}^{-3}$ & $15.8 \pm 3.98$ & $6.40 \pm 3.82$ & 0.41 & $253 \pm 877$ & $9.51 \pm 5$ & 0.38 \\
\hline $\mathrm{Rb}$ & $\mathrm{pg} \mathrm{m}^{-3}$ & $508 \pm 107$ & $405 \pm 174$ & 0.80 & $734 \pm 391$ & $584 \pm 308$ & 0.80 \\
\hline $\mathrm{Sr}$ & $\mathrm{ng} \mathrm{m}^{-3}$ & $0.860 \pm 0.19$ & $0.660 \pm 0.16$ & 0.77 & $1.40 \pm 0.75$ & $1.36 \pm 0.81$ & 0.97 \\
\hline $\mathrm{Th}$ & $\mathrm{pg} \mathrm{m}^{-3}$ & $26.8 \pm 13.7$ & $6.8 \pm 7.8$ & 0.25 & $67.5 \pm 47.3$ & $10.8 \pm 6.8$ & 0.16 \\
\hline $\mathrm{U}$ & $\mathrm{pg} \mathrm{m}^{-3}$ & $12.6 \pm 2.6$ & $4.3 \pm 3.5$ & 0.34 & $23.1 \pm 15.6$ & $5.1 \pm 4.0$ & 0.22 \\
\hline \multirow[t]{3}{*}{ V } & $\mathrm{pg} \mathrm{\textrm {m } ^ { - 3 }}$ & $1.50 \pm 0.23$ & $1.06 \pm 0.32$ & 0.71 & $2.43 \pm 0.56$ & $3.26 \pm 1.48$ & 1.0 \\
\hline & & \multicolumn{3}{|c|}{ Tokushima City (summer) } & \multicolumn{3}{|c|}{ Mountain area (winter) } \\
\hline & & {$[\mathrm{M}]_{\text {all }}$} & {$[\mathrm{M}]_{\mathrm{ws}}$} & {$[\mathrm{M}]_{\mathrm{ws}} /[\mathrm{M}]_{\mathrm{all}}$} & {$[\mathrm{M}]_{\text {all }}$} & {$[\mathrm{M}]_{\mathrm{ws}}$} & {$[\mathrm{M}]_{\mathrm{ws}} /[\mathrm{M}]_{\mathrm{all}}$} \\
\hline As & $\mathrm{ng} \mathrm{m}^{-3}$ & $1.03 \pm 1.00$ & $1.05 \pm 0.97$ & 1.0 & 0.87 & 0.39 & 0.45 \\
\hline $\mathrm{Ba}$ & $\mathrm{ng} \mathrm{m}^{-3}$ & $3.77 \pm 2.02$ & $2.13 \pm 1.77$ & 0.56 & 1.22 & 0.34 & 0.28 \\
\hline $\mathrm{Bi}$ & $\mathrm{pg} \mathrm{m}^{-3}$ & $321 \pm 291$ & $76 \pm 118$ & 0.24 & 245 & 4 & 0.02 \\
\hline $\mathrm{Cd}$ & $\mathrm{pg} \mathrm{m}^{-3}$ & $305 \pm 210$ & $233 \pm 212$ & 0.76 & 276 & 101 & 0.37 \\
\hline Co & $\mathrm{pg} \mathrm{m}^{-3}$ & $46 \pm 19$ & $20 \pm 17$ & 0.43 & 71.0 & 10 & 0.14 \\
\hline Cs & $\mathrm{pg} \mathrm{m}^{-3}$ & $72 \pm 59$ & $50 \pm 47$ & 0.69 & 119 & 46 & 0.39 \\
\hline $\mathrm{Cu}$ & $n g \mathrm{~m}^{-3}$ & $3.75 \pm 3.38$ & $2.82 \pm 2.86$ & 0.75 & 8.87 & 0.440 & 0.05 \\
\hline $\mathrm{Fe}$ & $\mathrm{ng} \mathrm{m}^{-3}$ & $95.0 \pm 85.5$ & $14.4 \pm 14.8$ & 0.15 & 119 & 4.60 & 0.04 \\
\hline $\mathrm{Ga}$ & $\mathrm{pg} \mathrm{m}^{-3}$ & $236 \pm 142$ & $158 \pm 109$ & 0.67 & 160 & 53 & 0.33 \\
\hline Mn & $n g \mathrm{~m}^{-3}$ & $4.35 \pm 1.17$ & $3.19 \pm 2.03$ & 0.73 & 4.20 & 1.67 & 0.40 \\
\hline $\mathrm{Pb}$ & $n g \mathrm{~m}^{-3}$ & $11.9 \pm 13$ & $5.33 \pm 6.25$ & 0.45 & 1.01 & 2.68 & 0.26 \\
\hline $\mathrm{Rb}$ & $\mathrm{pg} \mathrm{m}^{-3}$ & $300 \pm 179$ & $246 \pm 204$ & 0.82 & 444 & 207 & 0.47 \\
\hline $\mathrm{Sr}$ & $\mathrm{ng} \mathrm{m}^{-3}$ & $0.770 \pm 0.48$ & $0.660 \pm 0.57$ & 0.86 & 0.880 & 0.460 & 0.52 \\
\hline Th & $\mathrm{pg} \mathrm{m}^{-3}$ & $10.3 \pm 11.6$ & $1.6 \pm 4.2$ & 0.16 & 28.2 & I.I & 0.04 \\
\hline $\mathrm{U}$ & $\mathrm{pg} \mathrm{m}^{-3}$ & $4.8 \pm 5.1$ & $0.5 \pm 0.8$ & 0.10 & 12.4 & 1.4 & 0.11 \\
\hline $\mathrm{V}$ & $\mathrm{pg} \mathrm{m}^{-3}$ & $2.13 \pm 0.92$ & $2.44 \pm 2.33$ & 1.0 & 0.680 & 0.35 & 0.51 \\
\hline
\end{tabular}

starting point was $500 \mathrm{~m}$ for St. 1 and $1000 \mathrm{~m}$ for St. 2 and St. 3. Figure 2 shows typical examples of the backwards trajectory analysis. Atmospheric aerosols transported from the Asia continent, such as anthropogenic emissions and natural mineral dust, could have an effect in the winter (Nov. - Feb.) and the spring (Mar. - May), and relative contribution of aerosols derived from Japan, including ship emissions from the neighboring regions become larger in the summer (Jun. - Oct.).

\section{Acid soluble fractions in reference materials}

Table 3 gives the analytical results of trace elements, such as $\mathrm{Fe}, \mathrm{Co}$ and $\mathrm{Ni}$. The observed values were in agreement with the certified values within the experimental errors. However, unsatisfactory analytical results for $\mathrm{Al}$ and $\mathrm{Si}$ were obtained, suggesting that alminosilicate in CJ-1 could not be completely decomposed. This acid digestion technique could provide all contents of trace elements in aerosols, except for $\mathrm{Al}$ and $\mathrm{Si}$. The concentrations of trace elements in aerosols were defined as the "all component" ([M] all) in the aerosols.

Concentrations and enrichment factor of trace elements in aerosols

The average concentrations of trace elements in the acidsoluble and water-soluble fractions are shown in Table 4 after converting to the concentration in the atmospheric volume (ng $\mathrm{m}^{-3}$ or $\left.\mathrm{pg} \mathrm{m}^{-3}\right)$. The insoluble component $\left([\mathrm{M}]_{\text {insoluble }}\right)$ was 


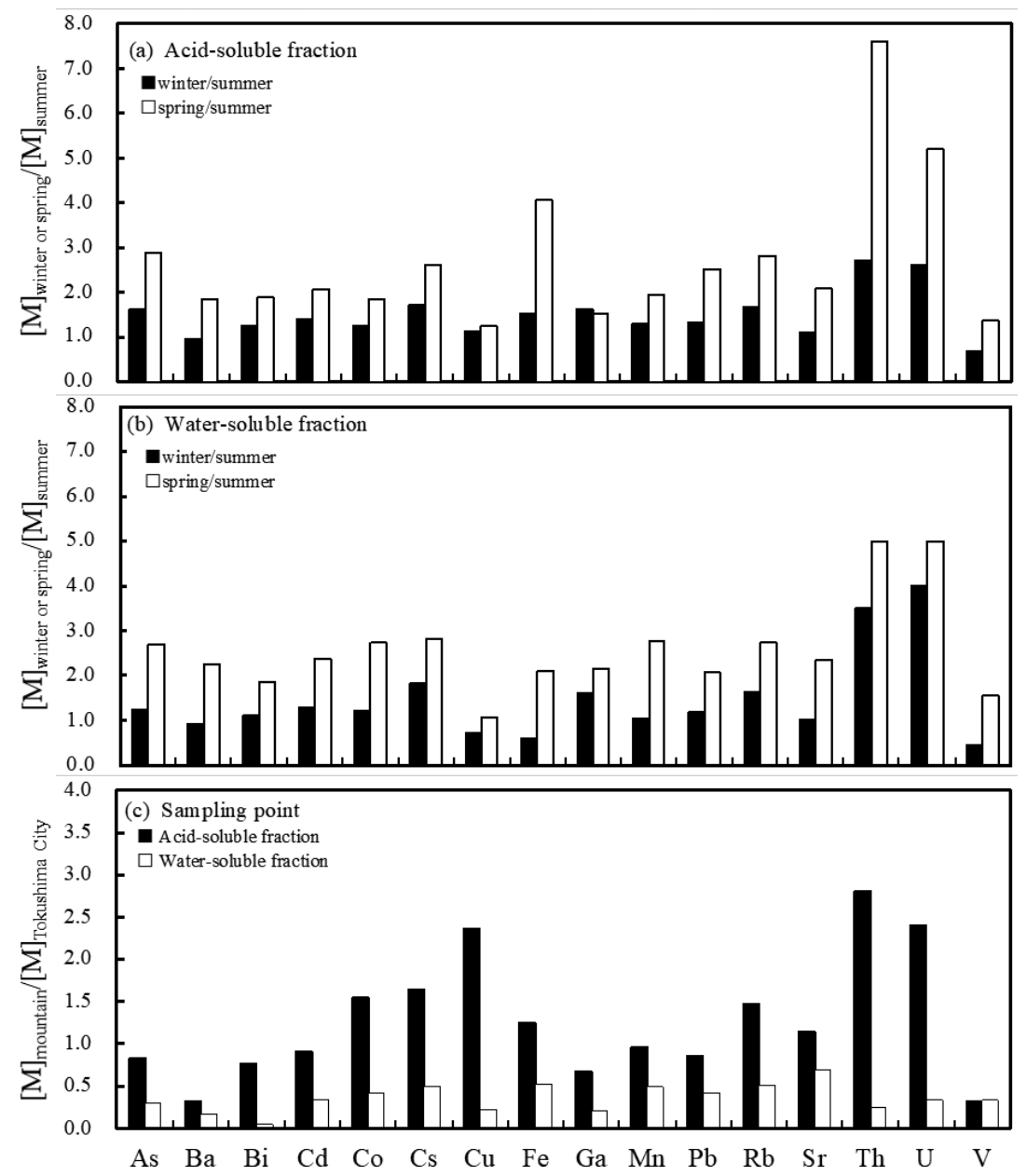

Fig. 3 Concentration ratios of trace elements for each season and sampling point: (a) The black column corresponds to the concentration ratios for the acid-soluble fraction between the winter and summer in Tokushima City, whereas the white column corresponds to that of the spring/summer. (b) The black column corresponds to the concentration ratios for the water-soluble fraction between the spring and summer in Tokushima City, whereas the white column corresponds to that of the spring/ summer. (c) The black column corresponds to the concentration ratios for the acid-soluble fraction between the mountain areas and Tokushima City in the winter, whereas the white column corresponds to that for the water-soluble fraction.

estimated by the difference of $[\mathrm{M}]_{\mathrm{all}}-[\mathrm{M}]_{\mathrm{ws}}$.

Atmospheric aerosols consist of a mixture of particles derived from various sources, such as crustal and anthropogenic (coal and petroleum combustion, industrial waste, domestic waste and urban dust) sources. The enrichment factor (EF) of a specific element, $\mathrm{M}$, is an indicator for the contribution of anthropogenic constituents. In this study, the EF value was calculated as

$$
\mathrm{EF}=\left([\mathrm{M}]_{\text {all }} /[\mathrm{Fe}]_{\text {all }}\right)_{\text {aerosol }} /([\mathrm{M}] /[\mathrm{Fe}])_{\text {crust }},
$$

where $\mathrm{M}$ is an element evaluated in this study, and ([M]/[Fe] $)_{\text {crust }}$ is a reference value of the surface crust proposed by Rudnick et al. ${ }^{26}$ An EF value higher than 100 indicates significantly the presence of particles derived from anthropogenic sources, whereas an EF value lower than 10 indicates less contribution from anthropogenic sources. In the case of pollutant elements, such as $\mathrm{Bi}, \mathrm{Cd}, \mathrm{Cu}$ and $\mathrm{Pb}$, the EF values of $\mathrm{Bi}(\mathrm{EF}: 375$ to 827 ), $\mathrm{Cd}(686$ to 1398$)$ and $\mathrm{Pb}$ (164 to 287) were higher than 100, and those of $\mathrm{As}(54$ to 93$)$ and $\mathrm{Cu}$ (41 to 129) were more than 10. The EF values of $\mathrm{Ba}, \mathrm{Co}, \mathrm{Cs}, \mathrm{Ga}, \mathrm{Mn}, \mathrm{Rb}, \mathrm{Sr}$, Th, $\mathrm{U}$ and $\mathrm{V}$ were less than 10 .

\section{Concentration ratios of trace elements}

Figure $3 \mathrm{a}$ gives the concentration ratios of trace elements in the acid-soluble fraction $\left([\mathrm{M}]_{\text {all }}\right)$ between seasons at Tokushima City. The average value of the ratio of $[\mathrm{M}]_{\text {all }}$ for the winter/ summer was $1.3 \pm 0.3$, except for $\mathrm{Fe}$, Th and $\mathrm{U}$, whereas that for the spring/summer was $2.0 \pm 0.5$. The ratios for Th and $\mathrm{U}$ were higher than those for other elements, suggesting that the increase rate of the $T h$ and $U$ concentrations in acid-soluble fraction in the winter and spring was larger than other elements compare to the summer. In the case of $\mathrm{Fe}$, the increase rate for the winter/summer was similar to those of other elements, whereas the increase rate for the spring/summer was larger than those of other elements. Figure $3 b$ shows the concentration ratio in the water-soluble fraction $\left([\mathrm{M}]_{\mathrm{ws}}\right)$ between seasons at Tokushima City. The average value of the ratio of $[\mathrm{M}]_{\mathrm{ws}}$ for the winter/summer was $1.1 \pm 0.4$, except for Th and $\mathrm{U}$, whereas that for the spring/summer was $2.3 \pm 0.5$. The ratios for Th and $U$ were higher than those for other elements. The increase rate of the Th and $\mathrm{U}$ concentrations in the water-soluble fraction in the winter and spring was larger than other elements compare to the summer, similar to the acid-soluble fraction. Figure $3 \mathrm{c}$ gives 

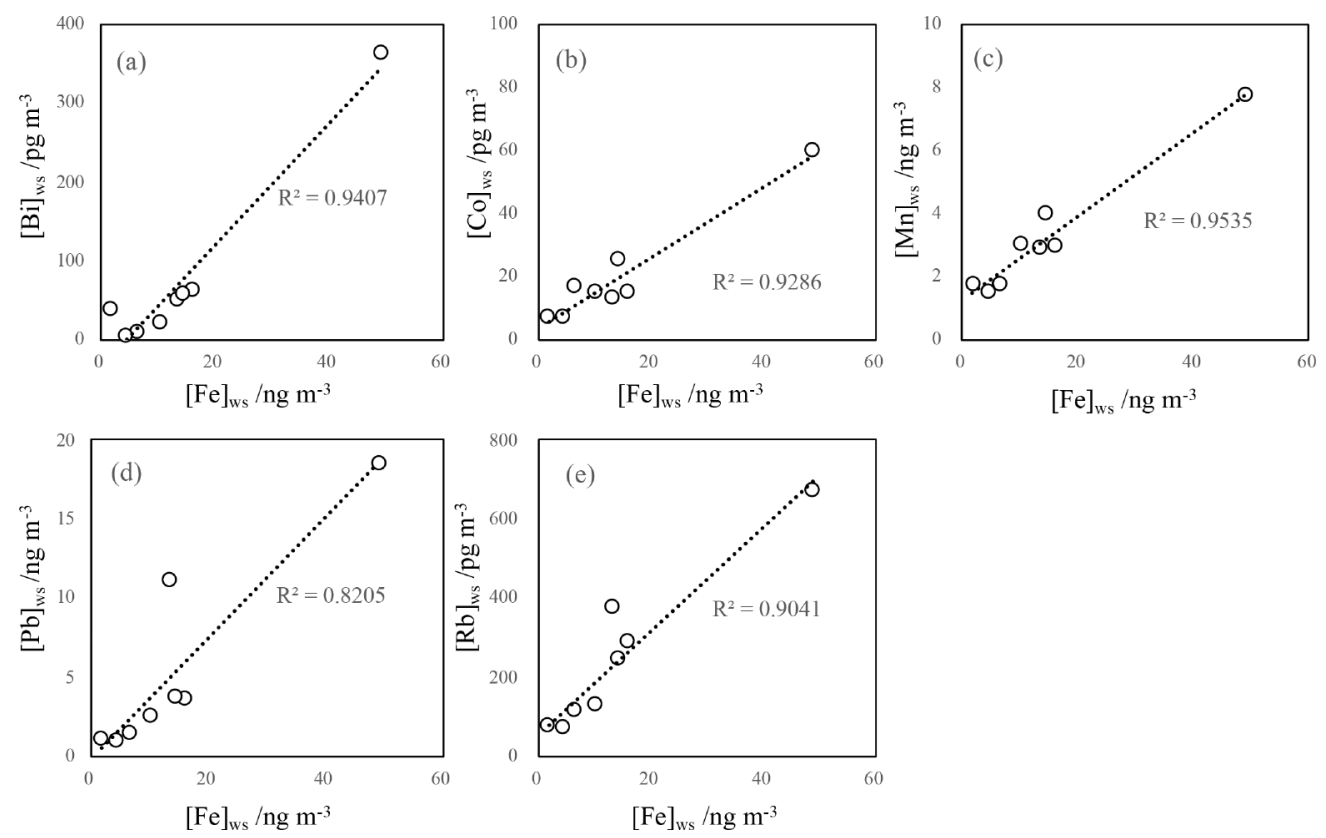

Fig. 4 Correlationship between $[\mathrm{Fe}]_{\mathrm{ws}}$ and $[\mathrm{M}]_{\mathrm{ws}}$ for Tokushima City in the summer. (a) $\mathrm{Bi}$; (b) Co; (c) $\mathrm{Mn}$; (d) $\mathrm{Pb}$; (e) $\mathrm{Rb}$. The dotted line is a regression curve for the plots.

the concentration ratios of trace elements between the mountain area and Tokushima City in the winter. In the case of the acidsoluble fraction, the ratios of $\mathrm{Co}, \mathrm{Cs}, \mathrm{Cu}, \mathrm{Fe}, \mathrm{Rb}, \mathrm{Sr}$, Th and $\mathrm{U}$ were larger than 1 . These elements had a small EF value of less than 10 , except for $\mathrm{Cu}$, suggesting that trace elements derived from natural mineral aerosols were enriched in the mountain area relative to Tokushima City. In the case of the water-soluble fraction, the ratios of all trace elements were smaller than 1 , suggesting that trace elements in the water-soluble fraction in Tokushima City were enriched relative to the mountain area. The total amount of trace elements, which can be micronutrients, such as $\mathrm{Co}, \mathrm{Cu}$ and $\mathrm{Fe}$, was abundant in the mountain area, but the water-soluble fractions for such elements were enriched in Tokushima City. In general, trace elements in anthropogenic aerosols through the burning process show a high watersolubility due to the great generation of fine particles. It is likely that aerosols in Tokushima City were affected from the Osaka-Kobe urban and the Setouchi industrial areas having a short distance from Tokushima City, implying that the trace elements in aerosols at Tokushima City had a higher bioavailability than those in the mountain areas. Our results were consistent with those report by Kurisu et al. ${ }^{17}$ that the water-solubility of $\mathrm{Fe}$ became higher in the aerosol fraction with a large contribution from anthropogenic sources.

The mean value of the water-soluble fraction $\left([\mathrm{M}]_{\mathrm{ws}}\right.$ ) against acid-soluble fraction $\left([\mathrm{M}]_{\text {all }}\right)$ is listed in Table 4. For anthropogenic elements, such as $[\mathrm{As}]_{\mathrm{ws}},[\mathrm{Bi}]_{\mathrm{ws}},[\mathrm{Cd}]_{\mathrm{ws}},[\mathrm{Cu}]_{\mathrm{ws}}$, $[\mathrm{Pb}]_{\mathrm{ws}}$, the $[\mathrm{M}]_{\mathrm{ws}} /[\mathrm{M}]_{\text {all }}$ value at Tokushima City was remarkably larger than that at the mountain areas. For crustal elements with a low EF value of less than 10, the seasonal variations were also unclear. The $[\mathrm{Fe}]_{\mathrm{ws}} /[\mathrm{Fe}]_{\text {all }}$ values in Tokushima City were 0.06 in the winter, 0.08 in the spring and 0.15 in the summer, respectively. Kurisu et al. ${ }^{17}$ also reported that the simulated rain-soluble $\mathrm{Fe}$ fraction of aerosols collected in Hiroshima, Japan increased from 0.07 to 0.14 and 0.06 to 0.27 with a decrease in the particle size from $5 \mu \mathrm{m}$ (coarse) to $0.45 \mu \mathrm{m}$ (fine) in March and August, respectively. A backward trajectory analysis suggested that spring samples were influenced by aerosols from East Asia, whereas summer samples had a weak contribution from East Asia. Nishikawa et al. ${ }^{22}$ also reported the $[\mathrm{M}]_{\mathrm{ws}} /[\mathrm{M}]_{\text {all }}$ values of aerosols with a particulate size larger than $2 \mu \mathrm{m}$ in Nagoya. According to the study, the $[\mathrm{M}]_{\mathrm{ws}} /[\mathrm{M}]_{\mathrm{all}}$ values of $\mathrm{Fe}(0.02), \mathrm{Pb}(0.27)$ and $\mathrm{V}(0.52)$ in Nagoya were close to those at the mountain areas, rather than Tokushima City. The $[\mathrm{M}]_{\mathrm{ws}} /[\mathrm{M}]_{\text {all }}$ value of $\mathrm{Cd}(0.99)$ at Nagoya was close to that at Tokushima City, whereas $\mathrm{Cu}(0.36), \mathrm{Mn}(0.52)$ and $\mathrm{Sr}(0.63)$ showed intermediate values between Tokushima City and the mountain areas.

\section{Correlationship between trace elements in the water-soluble fraction}

Figure 4 shows the typical correlationship between $[\mathrm{Fe}]_{\mathrm{ws}}$ and $[\mathrm{M}]_{\mathrm{ws}}$ at Tokushima City in the summer. A liner correlation was found for $[\mathrm{Bi}]_{\mathrm{ws}},[\mathrm{Co}]_{\mathrm{ws}},[\mathrm{Mn}]_{\mathrm{ws}},[\mathrm{Pb}]_{\mathrm{ws}}$ and $[\mathrm{Rb}]_{\mathrm{ws}}$, suggesting that these trace elements in the water-soluble fraction were derived from identical sources. Since the contribution from the Asian continents was small in the summer, the emission source was likely located at around Tokushima City. In contrast, $[\mathrm{Fe}]_{\text {all }}$ and $[\mathrm{M}]_{\text {all }}$ for such elements at Tokushima City in the summer did not show a liner correlationship, except for $[\mathrm{Rb}]_{\text {all }}$, suggesting that $[\mathrm{Fe}]_{\text {insoluble }},[\mathrm{Bi}]_{\text {insoluble }},[\mathrm{Co}]_{\text {insoluble }},[\mathrm{Mn}]_{\text {insoluble }}$ and $[\mathrm{Pb}]_{\text {insoluble }}$ were derived from different sources. It is likely that $[\mathrm{Rb}]_{\text {all }}$ was derived from the same sources with $[\mathrm{Fe}]_{\text {all }}$.

\section{Origin of trace elements based on the $\mathrm{Pb} / \mathrm{Cd}$ ratio}

Based on the differences in the $\mathrm{Pb} / \mathrm{Cd}$ ratio for aerosol samples between Japan and China, the $\mathrm{Pb} / \mathrm{Cd}$ ratio can be an index to discuss the origin of $\mathrm{Pb}$ and $\mathrm{Cd}$. Imai et al. ${ }^{13,14}$ reported that aerosols in Chinese cities show a high $\mathrm{Pb} / \mathrm{Cd}$ ratio of more than 30 due to coal burning, and that aerosols in remote areas of Japan also show a high $\mathrm{Pb} / \mathrm{Cd}$ ratio of more than 30 when the air mass comes from China, whereas the $\mathrm{Pb} / \mathrm{Cd}$ ratio in Osaka was 18. In this study, the $[\mathrm{Pb}]_{\text {all }} /[\mathrm{Cd}]_{\text {all }}$ ratios were $36-39$ in Tokushima City and 36 in the mountain areas, suggesting that $\mathrm{Pb}$ and $\mathrm{Cd}$ in aerosols of both sampling points mainly came from China. In contrast, the $[\mathrm{Pb}]_{\mathrm{ws}} /[\mathrm{Cd}]_{\mathrm{ws}}$ ratios were $19-22$ in 
Tokushima City and 26 in the mountain areas, suggesting that $[\mathrm{Pb}]_{\mathrm{ws}}$ and $[\mathrm{Cd}]_{\mathrm{ws}}$ partially came from Japan, and that the contribution of $[\mathrm{Pb}]_{\mathrm{ws}}$ and $[\mathrm{Cd}]_{\mathrm{ws}}$ from Japan was larger in Tokushima City relative to the mountain areas. In the case of the summer, although the typical back trajectories did not come from China, as shown in Fig. 2 , the $[\mathrm{Pb}]_{\text {all }} /[\mathrm{Cd}]_{\text {all }}$ ratio in Tokushima City was 39. At around 2013, July 20 and Aug. 10, a migratory cyclone and air mass flow from the southeast part of China were observed even in the summer. ${ }^{27}$ Therefore, the high $\mathrm{Pb} / \mathrm{Cd}$ ratio of more than 30 in the summer was affected by aerosols originated from China.

\section{Conclusions}

Our proposed method of combing aerosol sampling using a MCE membrane filter and filter digestion using $\mathrm{HNO}_{3}$ and $\mathrm{H}_{2} \mathrm{O}_{2}$ without $\mathrm{HF}$ were available for $\mathrm{Fe}, \mathrm{Cu}$ and $\mathrm{Ni}$, but not for $\mathrm{Al}$ and $\mathrm{Si}$. The concentrations of trace elements in the acid-soluble fraction of aerosols, all of components, were determined. The concentrations in the water-soluble fractions were also determined by water extraction. $\mathrm{As}, \mathrm{Bi}, \mathrm{Cd}, \mathrm{Cu}$ and $\mathrm{Pb}$ with a high $\mathrm{EF}$ value of more than 10 were derived from anthropogenic sources, whereas $\mathrm{Ba}, \mathrm{Co}, \mathrm{Cs}, \mathrm{Ga}, \mathrm{Mn}, \mathrm{Rb}, \mathrm{Sr}, \mathrm{Th}, \mathrm{U}$ and $\mathrm{V}$ with a low EF value of less than 10 were derived from natural crustal sources. Differences in both the acid-soluble and water-soluble fractions for each season were not found in Tokushima City. Due to the higher water-solubility of trace elements in aerosols at Tokushima City, trace elements in aerosols at Tokushima City may have higher bioavailability than that of the mountain areas. The origin of $\mathrm{Pb}$ and $\mathrm{Cd}$ in aerosols were mainly dominant from China, but water-soluble $\mathrm{Pb}$ and $\mathrm{Cd}$ were affected by aerosols from Japan.

\section{References}

1. K. H. Coale, K. S. Johnson, S. E. Fitzwater, R. M. Gordon, S. Tanner, F. P. Chavez, L. Ferioli, C. Sakamoto, P. Rogers, F. Millero, P. Steinberg, P. Nightingale, D. Cooper, W. P. Cochlan, M. R. Landry, J. Constantinou, G. Rollwagen, A. Trasvina, and R. Kudela, Nature, 1996, 383, 495.

2. S. Takeda and A. Tsuda, Prog. Oceanogr., 2005, 64, 95.

3. N. M. Price and F. M. M. Morel, Nature, 1990, 344, 658.

4. M. A. Saito and T. J. Goepfert, Limnol. Oceanogr, 2008, 53, 266.

5. J. A. Raven, New Phytol., 1990, 116, 1.

6. T. A.V. Rees and I. A. Bekheet, Planta, 1982, 156, 385.

7. T. Y. Ho, Limnol. Oceanogr, 2013, 58, 112.

8. S. Takano, M. Tanimizu, T. Hirata, and Y. Sohrin, Nature Commun., 2014, 5, 5663.
9. Y. Nakaguchi and A. Fujita, Bull. Soc. Sea Water Sci., Jpn., 2009, 63, 253.

10. A. E. Kelly, M. K. Reuer, N. F. Goodkin, and E. A. Boyle, Earth Planet. Sci. Lett., 2009, 283, 93.

11. S. C. Hsu, G. T. F. Wong, G. C. Gong, F. K. Shiah, Y. T. Huang, S. J. Kao, F. Tsai, S. C. C. Lung, F. J. Lin, I. I. Lin, C. C. Hung, and C. M. Tseng, Mar. Chem., 2010, 120, 116.

12. H. Tian, K. Cheng, Y. Wang, D. Zhao, L. Lu, W. Jia, and J. Hao, Atmos. Environ., 2012, 50, 157.

13. S. Imai, Y. Yamamoto, Y. Sanagawa, Y. Kurumi, I. Kurotani, J. Nishimoto, and Y. Kikuchi, Bunseki Kagaku, 2017, 66, 95.

14. S. Imai, Y. Yamamoto, K. Shimizu, E. Kanekio, J. Nishimoto, and Y. Kikuchi, Bunseki Kagaku, 2018, 67, 95.

15. Y. Yamamoto, E. Kanekiyo, K. Shimizu, G. Takahashi, M. Hashimoto, and S. Imai, Bunseki Kagaku, 2018, 67, 733.

16. W. Li, L. Xu, X. Liu, J. Zhang, Y. Lin, X. Yao, H. Gao, D. Zhang, J. Chen, W. Wang, R. M. Harrison, X. Zhang, L. Shao, P. Fu, A. Nenes, and Z. Shi, Sci. Adv., 2017, 3, e1601749.

17. M. Kurisu, Y. Takahashi, T. Iizuka, and M. Uematsu, $J$. Geophys. Res. Atmos., 2016, 121, 11119.

18. Y. Yamamoto, Y. Sanagawa, E. Kanekiyo, K. Shimizu, T. Yamamoto, and S. Imai, Bunseki Kagaku, 2018, 67, 349.

19. A. Ohta, H. Tsuno, H. Kagi, M. Nomura, R. Zhang, S. Terashima, and N. Imai, Geochem. J., 2006, 40, 363.

20. Y. Takahashi, M. Higashi, T. Furukawa, and S. Mitsunobu, Atmos. Chem. Phys., 2011, 11, 11237.

21. Y. Takahashi, T. Furukawa, Y. Kanai, M. Uematsu, G. Zheng, and M. A. Marcus, Atmos. Chem. Phys., 2013, 13, 7695.

22. M. Nishikawa, S. Kanamori, N. Kanamori, and T. Mizoguchi, Aerosol Kenkyu, 1984, 2, 294.

23. "Manual for Analysis of Components in Suspended Particulate Matter (SPM) and $\mathrm{PM}_{2.5}$ ", Ministry of the Environment, https://www.env.go.jp/air/osen/pm/ca/manual. html.

24. Q. Zhang, Y. Zheng, D. Tong, M. Shao, S. Wang, Y. Zhang, X. Xu, J. Wang, H. He, W. Liu, Y. Ding, Y. Lei, J. Li, Z. Wang, X. Zhang, Y. Wang, J. Cheng, Y. Liu, Q. Shi, L. Yan, G. Geng, C. Hong, M. Li, F. Liu, B. Zheng, J. Cao, A. Ding, J. Gao, Q. Fu, J. Huo, B. Liu, Z. Liu, F. Yang, K. He, and J. Hao, Proc. Natl. Acad. Sci. U. S. A., 2019, 116, 24463.

25. A. F. Stein, R. R. Draxler, G. D. Rolph, B. J. B. Stunder, M. D. Cohen, and F. Ngan, Bull. Amer. Meteor. Soc., 2015, 96, 2059.

26. R. L. Rudnick and S. Gao, Treatise on Geochemistry, 2003, 3,1 .

27. "Daily Weather Map", Japan Meteological Agency, https:// www.data.jma.go.jp/fcd/yoho/hibiten/index.html. 